\title{
Hanekom beslis nie die pad byster nie
}

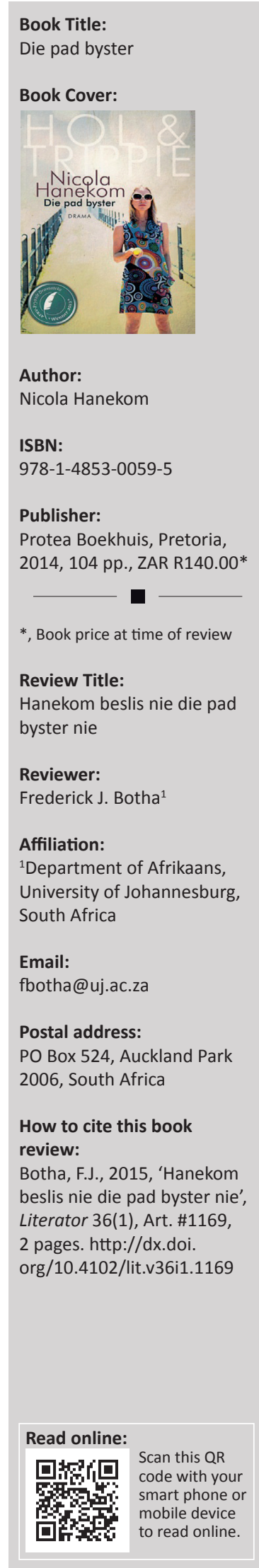

Afrikaanse drama is verryk met die publikasie van Die pad byster (2014) deur die veelbekroonde dramaturg én aktrise Nicola Hanekom, waarvoor sy in 2015 die Eugène Maraisprys ontvang. Dit bevat twee uitsonderlike dramatekste, 'Hol' en 'Trippie'.

'Hol' handel oor Liesbet wat soos 'n besetene op 'n trapmeul in 'n gimnasium hardloop terwyl sy haar obsessie met oefening en liggaamlike perfeksionisme probeer bevredig. Wanneer sy so naarstig oefen, konfronteer Liesbet, wat bulimies is, deur middel van innerlike monoloog nie net haar eetversteuring nie, maar ook donker geheime uit haar verlede. In 'Trippie' tref die leser 'n geheimsinnige vrou aan, met ' $n$ tas en 'n voorliefde vir appels, wat op 'n bus klim en 'n man met haar geselskap, veral haar grappies, amuseer. Hulle flirtasie verander spoedig in ongemak wanneer die man, 'n onlangse wewenaar, besef dat die vrou hom eintlik agtervolg.

'Hol' beeld die moderne mens se obsessie met die uiterlike, en veral met liggaamlike perfektheid uit. Omdat alles van buite af en op die oppervlak normaal moet lyk, word die mens se innerlike verwaarloos en dikwels ontken. Dit word reeds deur die titel gesuggereer, wat nie net verwys na Liesbet se fisieke oefening op die trapmeul nie, maar ook na die mens wat van donker geheime uit die verlede weghardloop, en terselfdertyd na die moderne mens wat as't ware hol is van binne weens sy leefwyse en obsessie met die uiterlike. In aansluiting hierby is dit die mens se obsessie met en afhanklikheid van kos, sowel as die vraatsugtige vergryping daaraan, al is dit net om uiteindelik soos Liesbet te 'binge', wat deurgaans in die dramateks oortuigend deursypel op 'n treffende dog ontstellende manier.

Tematies sluit 'Trippie' by 'Hol' aan deurdat 'Trippie' ook op menslike obsessie fokus. Die tema van ontvlugting verbind die dramas met mekaar. In 'Trippie' gee 'n obsessie aanleiding tot ' $n$ sielkundige riller wat die leser van begin tot einde aan die raai hou. 'Trippie' word as't ware 'n spel van liegstories, 'n sadistiese ontvlugtingspel om van die lewe se ongenaakbaarheid te vergeet.

Hanekom se vindingrykheid en vernuf by die keuse van tema, intrige, karakteruitbeelding en dialoog is opvallend in al twee dramatekste. Dit maak die lees van die dramas ' $n$ uitsonderlike belewenis, wat bewys hoekom resensente Hanekom ' $n$ teatergenie noem en waarom sy een van die gerekendste Afrikaanse dramaturge is. In 'Hol' maak Hanekom uitsluitlik gebruik van die innerlike monoloog van Liesbet, wat verbete op die trapmeul oefen. Hierdie gedagtereis, sonder sensuur, word op só 'n effektiewe manier aangewend om Liesbet se innerlike stryd weer te gee, dat die monoloog nie bloot net nog 'n eenvrouvertoning word nie, maar 'n soort bewussynstroomvertelling wat die ontstellende wêreld van veral eetversteurings belig. Hanekom beïndruk in beide dramas met haar meesterlike woordspel wat haar uitsonderlike talent as woordkunstenaar bevestig. Veral 'Trippie' betrek bykans poëtiese elemente by die karakters se dialoog.

Aan die ontwikkeling van haar temas gee Hanekom struktuur deur inspirasie te put uit verskeie intertekste wat strek vanaf die Calvinistiese godsdiens, die sosio-maatskaplike probleme in SuidAfrika tot die lewe van Hollywood se glanspersoonlikhede. Dit blyk veral in 'Hol', wat 'n dimensie van betrokke literatuur aan die drama verleen. Een sentrale intertekstuele verwysing in beide dramatekste is die verwysing na Eva: in 'Hol' argumenteer Liesbet dat Eva waarskynlik die eerste verslaafde aan suiker was wat moontlik haar appels in toffie gedoop het. Die Eva-figuur vind ook neerslag in 'Trippie' waar die vrou op die bus, oftewel Miela, die man op die bus met haar suur appels verlei tot hy uiteindelik die hoofrol in haar sinistere gruwelspeletjie vertolk.

Die pad byster bevat twee dramatekste wat allermins voorspelbaar en vervelig is, maar die leser meevoer tot in die menslike psige wat deur Hanekom ontbloot word, en wat uiteindelik afstuur 
op onverwagse, duistere maar deurgaans verrassende ontdekkings. Die geslaagdheid van beide dramatekste lê daarin dat hulle enersyds toeganklik en vermaaklik vir die algemene leserspubliek is, maar andersyds ' $n$ byna filosofiese kwaliteit verkry wat intellektuele diepte aan die tekste verleen.

Die dood van Reza de Wet, een van die belangrikste en mees talentvolle vroulike dramaturge in Afrikaans, het ' $n$ groot leemte in die Afrikaanse drama gelaat. Met toneelstukke soos haar trilogie van plekspesifieke teater, Betésda, Lot en Babbel, haar ruimtelike drama, Land van skedels, en die veelbekroonde Hol en Trippie, kan die Afrikaanse letterkunde én Afrikaanse teatergangers maar gerus wees - die Afrikaanse drama is in die uiters bekwame hande van Nicola Hanekom. 'n Mens kan net hoop dat meer van haar grensverskuiwende dramas gepubliseer sal word. Dit sal onomwonde bydra tot die skatkis van die Afrikaanse drama. 